
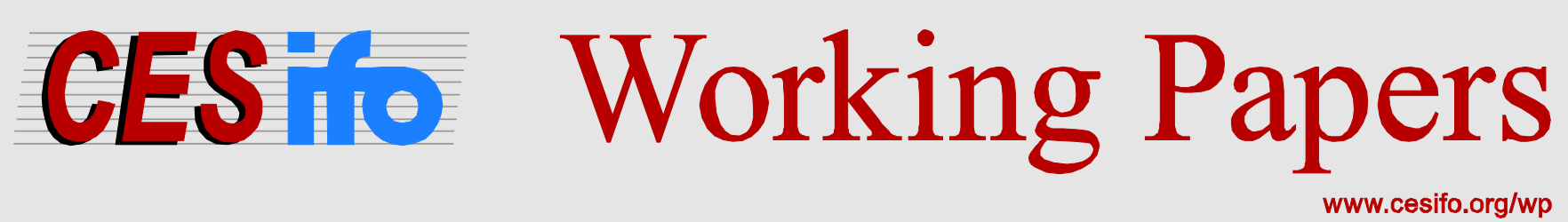

\title{
Biased Policy and Political Behavior
}

\author{
Avi Ben-Bassat \\ Momi Dahan
}

CESIFO WORKING PAPER NO. 6269

CATEgory 2: Public ChOICE

DECEMBER 2016
An electronic version of the paper may be downloaded
- from the SSRN website: Www.SSRN.com
- from the RePEc website: Www.RePEc.org
- from the CESifo website: www.CESifo-group.org/wp




\title{
Biased Policy and Political Behavior
}

\begin{abstract}
Unlike the previous literature on mass policy feedback, the present paper argues that a negative message embodied in public policy may foster or dampen political participation depending on social group affiliation. The policy change we use to examine the effect of biased policy (a negative message) on political behavior is the removal of elected mayors that were replaced by an appointed committee in a large number of Arab and Jewish municipalities in Israel which was skewed significantly towards Arab municipalities. We show that Arab voters in intervened municipalities are more likely to show up in the ballot boxes in national elections and they tend to vote more for Arab parties. In contrast, the political participation of Jewish citizens is lower in municipalities with an appointed council without noticeable effect on vote choice.
\end{abstract}

JEL-Codes: D700, D720, D740.

Keywords: policy feedback, political participation, vote choice.

\author{
Avi Ben-Bassat \\ Department of Economics \\ The Hebrew University of Jerusalem \\ Mount Scopus \\ Israel - 91905 Jerusalem \\ avibb@huji.ac.il
}

\author{
Momi Dahan* \\ School of Public Policy \\ The Hebrew University of Jerusalem \\ Mount Scopus \\ Israel - 91905 Jerusalem \\ momidahan@mscc.huji.ac.il
}

*corresponding author

We thank Esteban F. Klor for fruitful discussions of an earlier version of the paper. We have benefited also from comments by Mariana Lopes da Fonseca, Pavel Jenlov, seminar participants at The School of Public Policy in the Hebrew University of Jerusalem, Israel Democracy Institute, the IIPF 71th conference in Dublin (Ireland), and European public Choice Society 2016 conference in Freiburg (Germany). We thank Ariel Goldstein and Nathan Hemmendinger for their excellent research assistance. 


\section{$\underline{\text { Introduction }}$}

Policies are not only the outcome of politics, they also shape the political process through the messages they convey and subsequently impact future policies. In his influential paper, Pierson (1993) shows that public policy may affect politics also by altering individuals' resources and incentives. ${ }^{2}$ Yet, the policy feedback literature devoted significant research efforts to explore the interpretive effects of public policy on politics as compared to the effects of resources (Verba et al 1995) or incentive channels (Campbell 2003). Schneider and Ingram (1993) offer an intriguing theoretical argument, that certain groups are expected to have a negative experience with government, which dampens their standard modes of political participation such as voting.

In a series of empirical works, scholars have studied the effect that personal experience with public policy may have on conventional forms of political behavior in an attempt to uncover the link between policies and politics. Soss (1999) was one of the first to find that recipients of means-tested welfare programs are less active than recipients of SSDI (Social Security Disability Insurance), even after controlling for individual characteristics. Using in-depth interviews, Soss (1999) attributed the lower level of political participation to the negative experience that clients of meanstested programs went through, such as ongoing scrutiny to prove their eligibility, threats of termination of welfare benefits, and the compulsion to share intimate information. Bruch et al (2010) show that political participation varies even within means-tested programs. They employ a convincing identification strategy to examine three types of means-tested programs of public assistance (Head Start, Housing Aid, and Temporary Assistance to Needy Families), and find that the recipients of a welfare program with a paternalistic design are less likely to participate in the political process. As expected, the positive policy experience of veterans benefitting from the GI Bill has fostered their political and civic participation (Mettler 2005). These important studies, among others, lend strong empirical support that negative

\footnotetext{
${ }^{2}$ The potential effects of policy on politics was first explored in the seminal work of Schattschneider (1935) on the politics of tariffs.
} 
interpretive messages reduce political participation and positive experiences enhance it. $^{3}$

Unlike the previous literature on mass policy feedback, the present paper argues that negative messages embodied in public policy may foster or dampen political participation, depending on social group affiliation and context. Miller and Krosnick (2004) have already examined the effects of perceived undesirable policy change on political behavior. They have exploited a field experiment and have shown that a letter highlighting undesirable policy changes, which was sent to potential contributors, increased the number of financial contributions made to a political lobbying organization. However, this interesting study has not studied that effect in the social context of ethnic and minority groups. Other scholars have investigated the importance of social context, but not in relation to policy making. Schildkraut (2005) has found that individual-perceived discrimination (self-reported) has a positive effect on political engagement of Latinos. In addition, there are several studies that examine the effects of general political climate on political participation of ethnic and minority groups. Pantoja et al (2001) find that Latinos who chose to naturalize in California in 1992-96 are more likely to vote, as compared to Latinos who had naturalized in California before that time period and to their contemporaries in Texas and Florida. They attributed that effect to the hostile political environment toward Latinos in California in that period of time. Cho et al (2006) have also offered evidence on the effect of hostile environments on political participation. They have shown that the political participation of Arab Americans has increased after 9/11, as a result of a hostile climate, which was measured by the prevalence of the terms "Patriot Act" or "war in Iraq" in the news.

Introducing the interplay between social group consciousness and biased policy associated with a negative message such as discrimination, leads to higher rather than lower political participation of certain groups. ${ }^{4}$ Our conceptual framework postulates

\footnotetext{
${ }^{3}$ Campbell (2012) provides a review of this literature with reference to the effects of policy in other fields on politics. Note that Soss and Schram (2007) do not find evidence of welfare policy reforms changing public opinion.

${ }^{4}$ Adding the nature of interaction between social groups and in particular between the dominant group and minority/ethnic groups seems to be one of the more promising routes to account also for the significant variation across various social groups in political engagement and vote choice. The differences in group political engagement have been empirically attributed to group identity or consciousness (e.g., Miller et al 1981, Wilcox and Gomez
} 
that a biased policy provokes social group consciousness regarding the relative position in society among individuals with minority group affiliation, which in turn contributes to a higher sense of internal efficacy and consequently generates the unusual combination of low external political efficacy with high internal political efficacy. As a result, the target population with minority affiliation is expected to be more active in the political process as long as they have at least minimal faith in the political system.

However, the same policy may dampen the political participation among the target population that belongs to the majority group as a result of a lower level of external and internal political efficacy. In contract to the minority group, our expectation regarding the target population affiliated with the majority group resembles the political behavior predicted by previous scholars (e.g., Schneider and Ingram 1993).

The policy change we use to examine the effect of biased policy on political behavior is the removal of elected mayors that were replaced by an appointed committee in a large number of Arab and Jewish municipalities in Israel in the 2000s. The central government intervention was not uniformly distributed across sectors; the appointment of summoned committees was skewed significantly towards Arab municipalities. The policy intervention in a relatively large number of Arab municipalities (more than their share) has been perceived as a discriminatory act by Arab citizens. We show that Arab citizens in intervened municipalities are more likely to show up in the ballot boxes in national elections, and that they tend to vote more for Arab parties as compared to Arab municipalities without intervention. In contrast, the political participation of Jewish citizens is lower in municipalities with appointed council without noticeable effect on vote choice as compared to the general Jewish population.

This paper advances our understanding of the interpretive effects embodied in public policy on political behavior. A negative message may produce the opposite political response from the one that was traditionally suggested in the mass policy feedback literature. Employing a general policy change allows us to provide empirical support

1990, Ben-Bassat and Dahan 2012), ethnic-based institutions that encourage mobilization (e.g., Tate 1991, Rosenstone and Hansen 1993, Harris 1994, Verba, Schlozman and Brady 1995, Brown and Brown 2003), and political empowerment (e.g., Bobo and Gilliam 1990, Tate 1994, Pantoja and Segura 2003, Washington 2006, Logan et al 2012). 
to that prediction by comparing the political behavior of target population and general population in both majority and minority groups following that policy change.

Our second contribution refers to the role of public policy in explaining the variation in political behavior across social strata, and in particular that of subordinate-minority groups which could not be accounted for by differences in individual or institutional characteristics. While the previous literature has made an important contribution in studying the individual and institutional factors, our understanding of political behavior of ethnic and minority groups is still at its infant stage. ${ }^{5}$ It is imperative to study the differences in political behavior of social groups in light of the changing social structure of nation states, that is far more heterogeneous today than it was after World War II.

The third major contribution of our empirical examination is providing an explanation that may account for the substantial fluctuations over time in political participation and political preferences. Standard prevailing explanations of political participation and vote choice that rest on relatively stable resources, such as education or income and mobilization strategies, could not explain the relatively large fluctuations in voter turnout from election to election.

In the next section we describe the centralization program that was launched in Israel in the 2000s and the attitudes toward that policy change among different social groups. Section 3 presents a conceptual framework that guides our empirical investigation regarding the link between biased public policy and political participation and voting behavior of minority and majority groups. Section 4 presents the empirical analysis and section 5 concludes.

\section{$\underline{\text { 2. Policy change and attitudes }}$}

\footnotetext{
${ }^{5}$ Recently, Logan et al (2012) as well as Leighley and Nagler (2013) have shown once again that certain groups, such as African-Americans, vote at higher rates than Anglos, while the political engagement of other groups (Latinos and Asian-American) is lower as compared with Anglos, after controlling for standard SES (socioeconomic status) factors such as education, income and age. See also Tate $(1991,1994)$ and Leighley $(2001)$ for similar findings.
} 
This research focuses on the potential difference in political reaction to a major policy change in terms of political participation and political preferences of citizens that belong to dominant and minority groups. The same policy change may be perceived differently by individuals, conditional on their social group affiliation, and regardless of the true motivations that stand behind that policy act.

\subsection{The policy change}

The policy change we use is the appointment of a summoned committee in a large number of Arab and Jewish municipalities in Israel. Following a severe fiscal crisis in municipalities in Israel during the years 2001-2003, the central government launched a major economic program that affected more than half of the Jewish municipalities and more than $90 \%$ of Arab municipalities (Ben-Bassat and Dahan 2009). To cope with that fiscal crisis, the Interior Ministry employed two "soft" measures of administrative subordination (an appointment of an accountant that has to approve in advance every expense of the municipality and the imposition of a recovery program) and a more intrusive measure which removes the elected mayor and members of the local council and appoints a summoned board as the sole authority of the municipality until the next local election. ${ }^{6}$

According to stated policy, the interior ministry removes elected officials who are replaced by appointees in municipalities with a budget deficit over 15 percent of its total revenue, short-term debt over 30 percent of its total revenue and tax effectiveness indicator below a certain threshold. In addition, the elected local council is dismissed if it does not approve the budget within three months of the beginning of the fiscal year.

In a relatively short period of time, from 2005 through 2011, the elected mayors and members of local councils were replaced by a summoned board in 30 municipalities. The number of new summoned boards in the last decade exceeds that of all previous five decades combined (Ben-Bassat, Dahan and Klor 2016a). This policy change was not uniformly distributed: a summoned committee was the sole authority in 21 out of

\footnotetext{
${ }^{6}$ See Ben-Bassat, Dahan and Klor (2016b), for a detailed description of the local election system in Israel.
} 
80 Arab municipalities as compared to 9 out of 110 Jewish municipalities. ${ }^{7}$ This is in contrast with the former actual policy of the central government where the very few summoned committees that had been appointed in the past were distributed evenly between Jewish and Arab municipalities (i.e. according to their shares in the population).

The implementation of the policy to appoint summoned committees was determined according to pre-specified rules and with very little discretion, thus leaving slim room for discrimination. Ben-Bassat, Dahan and Klor (2016a) have shown that the imposition of appointed committees was closely related to local fiscal stress measures. Yet, that policy reform may still be perceived as discriminatory by Arab residents. The poor tax capacity of many Arab municipalities may reflect general policy biases, such as government refusal to expand jurisdiction area of Arab municipalities, lack of commercial and industrial zones in Arab municipalities (due to past biased incentive policies), and equalization grant policy. Arab leaders frequently claim that the poor fiscal conditions in Arab municipalities are mainly the result of those disparities that are rooted in past and present discrimination. Therefore, while the implementation of the rules that govern the appointment of summoned committees might not be ethnically biased, Arab citizens may still perceive that policy as discriminatory.

\subsection{Attitudes toward appointed committees by ethnic origins}

While the central government has stated that poor local management is the key factor behind fiscal crises, others blame the combined effect of general economic slowdown (that leads to lower revenue) and the dramatic cuts in equalization grants to poor municipalities as the main causes of fiscal distress in the beginning of the 2000s. As a result, one could blame either the central government or local elected officials for the ballooned debts and deficits of municipalities.

The uncertainty regarding the root cause of local fiscal crises opens the door to different interpretations of central government intervention. The same policy may be

\footnotetext{
${ }^{7}$ A municipality is defined Jewish (Arab) if more than a half of its residents are of Jewish (Arab) origin. In general, Jews and Arabs reside in separate municipalities except 8 large cities like Jerusalem and Tel-Aviv where both Jews and Arabs live together (the average share of Arabs in those cities is around 20\%). We exclude regional municipalities due to data limitations.
} 
perceived differently by various social groups depending in part on the level of trust that individuals have in the government. According to the Israel Democracy Institute's yearly survey, Arab citizens in Israel consistently show a lower degree of trust in government as compared to Jewish citizens. Around 60 percent of Arab respondents do not trust the government at all, relative to 33 percent among Jewish individuals (Herman et al, Israeli Democracy Index 2013; 42).

Beeri and Yuval (2013) provide direct evidence on the level of support for central government intervention in running local municipalities by ethnic origin (i.e. national majority and minority groups). Their survey of 1,321 residents of 156 municipalities specifically covers questions on the respondents' attitudes toward appointed committees. For example, one of the questions is: "In cases of local crisis, replacing the elected leadership with a convened committee appointed by the Ministry of Interior is an appropriate decision". They found that residents of municipalities without an appointed committee tend to support such intervention but residents in intervened municipalities are more likely to oppose it. They show also that Arab residents are more likely to oppose the removal of elected local mayors and councilors as compared to Jewish residents. Taken together these two findings imply that the attitudes of residents in municipalities with an appointed committee are different conditional on their ethnic (minority) origin. ${ }^{8}$

Arab citizens in municipalities view the act of removing their elected mayors and council members and replacing them by the Interior Ministry appointees as a threat to their fundamental rights rather than a tool to guarantee adequate level of local services (El-Taji, 2008). The dissatisfaction of Arab citizens has translated into frequent violent instances against the Interior Ministry appointees including two failed attempts to assassinate the head of the summoned committee in Tayibe and Turan. The national Arab leaders in the Israeli parliament have headed the opposition to these policy measures and in particular to summoned committees. In fact, Arab parties in the parliament have issued a motion of no-confidence against the government in 2009 to express their resistance to appointed local councils in Arab

\footnotetext{
${ }^{8}$ In the multiple regression analysis, Beeri and Yuval (2013) found that ethnicity (minority) has a significant coefficient while the appointed committee has the expected sign but is insignificant. However, the coefficient of an appointed committee becomes significant after excluding ethnicity (minority).
} 
municipalities. One might find signs of dissatisfaction also in Jewish municipalities regarding summoned committees but there was no national party that challenged the government on this particular issue and naturally discrimination was not brought up.

As mentioned before, the appointed council has been used disproportionally in Arab municipalities and against the will of their residents. Moreover, all of the summoned committees in Arab municipalities were first headed by appointees of Jewish origin. These two facts have been used by national and local Arab leaders in Israel to claim that this policy change is discriminatory in nature. The National Committee of Chairmen of Arab Local Authorities (NCCAL), which is a leading organization of Arab citizens in Israel, has expressed the strongest rejection to the use of appointed committees in Arab municipalities and have organized a general strike in all Arab municipalities following the decision of Interior Ministry to dismiss local elected officials. ${ }^{9}$ The spokesmen of NCCAL also voiced this dissatisfaction in the international outlet of Kul el Arab, stating that the policy tool of an appointed committee targets the Arab population and undermines the legitimation of its elected leadership. ${ }^{10}$ The word discrimination may be found numerous times in Arab NGO reports or websites and in popular press in Israel regarding summoned boards. ${ }^{11}$ Naturally, this type of claim has not been raised in Jewish municipalities with a summoned committee.

Thus, there is much evidence to conclude that this same policy change has been perceived differently by minority and dominant groups. In particular, the central government intervention led to an increased sense of threat and dissatisfaction especially among Arab residents. In the empirical analysis, we use the appointed summoned committee that was instituted by the central government as our (indirect) measure of dissatisfaction or perceived discrimination.

\section{Modelling the link between public policy and political behavior}

We argue here that public policy is linked to political behavior through its differential impact on external political efficacy (defined as the intensity of beliefs that the

\footnotetext{
${ }^{9}$ NRG website, on June 29, 2007.

${ }^{10}$ Kul al Arab, July 6, 2007 (page 4).

${ }^{11}$ See for example the report for 2012 published by The Coalition Against Racism in Israel (p. 24). See also the column by Ali Hider in TheMarker (Haaretz) on October 18, 2012.
} 
government is responsive) and internal political efficacy (defined as the feeling that an individual political action could have an impact on the political process). The main core of our thesis here is that the removal of local elected mayors and councilors produces an unusual mixture of lower external political efficacy and higher internal political efficacy among the target population (as compared to the general population) in the minority group, that fosters their political participation. In contrast, the same policy generates a standard combination of lower external and internal political efficacy among the target population (as compared to the general population) in the majority group, that depresses their political participation. Fluctuations in the level of political efficacy as a result of a biased policy change may translate into changes in political participation and vote choices. This prediction rests on prior research that has established a solid link between both dimensions of political efficacy and political participation (Verba and Nie, 1972; Shingles, 1981; Finkel, 1985; Niemi et al 1991; Rosenson and Hansen, 2003). ${ }^{12}$

We argue that ethnically-biased public policy as perceived by the minority group raises group consciousness, and following Shingles (1981), that contributes to a higher level of internal political efficacy among individuals of the target population who are affiliated with that minority group. We borrow the concept of group consciousness from Miller et al (1981) who argue that "group consciousness involves identification with the group and a political awareness or ideology regarding the group's relative position in society along with a commitment to collective action aimed at realizing the group interest'. ${ }^{13}$ The last part of this definition of group consciousness represents our notion of internal political efficacy and it would be natural to label it as group-consciousness-based internal political efficacy.

As we discuss above there is strong evidence that Arab citizens especially in intervened municipalities view the imposition of appointed committees as an act of discrimination by the central government. As Beeri and Yuval (2013) show, the

\footnotetext{
${ }^{12}$ See Morrell (2003) for extensive review of this line of research.

${ }^{13}$ The definition of Miller et al (1981) of group consciousness covers four components: social identification, the extent of in-group positive affect and out-group dislike (polar affect), the level of satisfaction with the group's relative position (polar power) and the perceived responsibility of the political system for the group's relative position in society (individual vs system blame). Our conceptual framework emphasizes the likely interaction between public policy and the effect of the last component of group consciousness definition on internal and external political efficacy.
} 
reduction in local autonomy of Arab residents has been done by the central government against the will of citizens in intervened Arab municipalities (the Arab target population). We assume that the policy intervention raises group consciousness of Arab citizens and political awareness regarding their deprived position in the general population and their dedication to political action to promote their cause. As suggested by Shingles (1981), rising group consciousness leads to a higher sense of internal political efficacy among Arab citizens in intervened municipalities. Consequently, a higher level of political participation on behalf of the group and more votes to affiliated parties are natural actions to advance their interests.

Unlike Jewish municipalities, Arab municipalities already had the organizations needed to exploit the increased sense of dissatisfaction that is associated with the policy change to gain more votes. A body of evidence suggests that political mobilization is a direct response to the degree of threat and discrimination a group experiences (Salamon and Van Evera 1973, Miller et al 1981, Feldman and Stenner 1997, Marcus et al 2000, Rudolph et al 2000, Campbell 2003, Valentino et al 2011, Austin et al 2012). There is direct evidence that Arab parties in the Israeli parliament have used the imposition of summoned committees as a mobilizing argument during national elections. ${ }^{14}$ Using such tactics is expected, given the work in psychology that has suggested that the perception of threat motivates affiliation with others who also feel threatened (Schachter 1959, Gump and Kulik 1997, Lowenstein et al 2001).

The effect of ethnically biased policy change on external political efficacy is straightforward as it reduces the perceived responsiveness of the government in the eye of the minority group, especially among the target population. The effect of a reduced external political efficacy on political participation is supposed to be quite small given the already low degree of trust in the central government among Arabs as cited above.

Thus, the mentioned policy change is predicted to result in lower trust in government responsiveness together with a higher level of internal political efficacy among individuals of the target population affiliated with the minority group which

\footnotetext{
${ }^{14}$ See for example the following video by RAAM TAAL (an Arab party in the Israeli

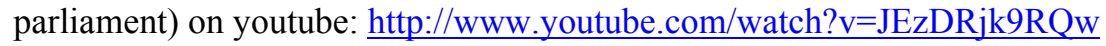


resembles the mistrust-low sense of political efficacy hypothesis suggested first by Gamson (1968). The lower level of external political efficacy creates the need to act (demand side) and the higher sense of internal efficacy produces the ability to act (supply side). Arab residents in municipalities with an appointed committee are expected to experience a higher degree of internal political efficacy and as a result are anticipated to be more susceptible to political mobilization as compared to general Arab population in municipalities without intervention (or before the intervention). After all, the central government appointees are present in their own municipality. Therefore, Arab individuals who live in intervened municipalities (target population) are predicted to have higher rise in political participation than the rest of the Arab population in Israel, which benefits the Arab parties who gain more votes.

As Beeri and Yuval (2013) found, the target population in Jewish municipalities opposed the intervention which implies that residents in intervened municipalities have perceived the removal of their local elected representatives as yet another way to cut poor sections in the Israeli society from participating in local decision making rather than an insurance devise to deal with failed mayors (electoral-error-correction). The intervention may even further decrease the low sense of external political efficacy that characterizes poor people in general. Unlike the Arab citizens, no organization or political party has emerged to frame the policy intervention in terms of social affiliation to mobilize voters in Jewish citizens in affected municipalities. As a result, the policy intervention should dampen their perceived ability to affect the political process and the subsequent policy. The likely response to such intervention in Jewish municipalities is a reduction in both the level of external political efficacy and their sense of internal political efficacy that contributes to a lower level of political participation. In contrast, individuals in the Jewish general population (i.e. Jewish municipalities without an appointed council) are likely to gain from the change in public policy. The intervention would reduce the potential bailout costs associated with poor management or strategic behavior by municipalities in weak fiscal conditions. Thus, they are anticipated to back the intervention and indeed Beeri and Yuval (2013) lend support to that prediction. Serving the interests of residents in municipalities with healthy fiscal conditions should increase their sense of external political efficacy as well as internal political efficacy and as a result their political participation. 
We believe a convincing case has been established that the intervention in the form of removal of local elected officials has generated an impact on both internal political efficacy through its effect on perceived discrimination and external political efficacy; all the while, we must admit that the empirical examination represents a reduced-form estimation of the link between policy change and political participation fluctuations, assuming that internal and external political efficacy are the mediating factors. We summarize this discussion by presenting our four key hypotheses:

H1: The imposition of an appointed committee in Arab municipalities is expected to increase the political participation of their residents in national elections as compared to Arab residents in municipalities without appointed committees.

H2: The imposition of an appointed committee in Jewish municipalities is expected to reduce the political participation of their residents in national elections in comparison with Jewish residents in municipalities without appointed committees.

H3: Arab residents in municipalities where elected officials were replaced by summoned committees would increase their votes for Arab parties in national elections as compared to Arab residents in municipalities without appointed committees.

H4: Jewish residents in municipalities would not change their vote choice regarding the share of votes for Arab parties in national elections following the imposition of an appointed committee.

\section{$\underline{\text { 4. Empirical Analysis }}$}

\subsection{The estimated models}

To test our hypotheses, we exploit a panel dataset on actual voting turnout and political preferences in the last three national elections in Israel for all municipalities. We estimate the effect of perceived discrimination that is associated with a major policy change on political participation using the following statistical model:

$$
\text { (1) } \text { Turnout }_{i, t}=a(\text { appointed committee })_{i, t}+\mathbf{X}_{i, t} \mathbf{b}+c_{t}+d_{i}+u_{i, t}
$$

where Turnout $_{i t}$ is the share of eligible voters who show up in the ballot boxes in municipality $i$ at election $t$. The summoned committee is a dummy variable that gets 1 
if the authority in municipality $i$ is in the hands of appointed officials at the time of election $t$, and zero otherwise. We use the same timing for both turnout and summoned committee to capture the saliency of that central intervention during national election. $\mathbf{X}_{i t}$ is a vector of time-varying municipality characteristics; $c_{t}$ is a fixed effect for each election year in the sample to control for general trends; $d_{i}$ is a municipality fixed effect; $\alpha$ and the vector $\mathbf{b}$ are unknown parameters that would be estimated. Unobserved determinants of political participation at the municipality level are represented by the error term, $u_{i t}{ }^{15} \mathrm{We}$ estimate Equation (1) for Arab and Jewish municipalities separately, and as suggested in hypotheses $\mathrm{H} 1$ and $\mathrm{H} 2$, the estimated coefficient $a$ should be positive in Arab localities and negative in Jewish municipalities.

The concern of selection bias is natural here given that the intervention is not random but rather those municipalities were chosen by the Ministry of Interior based on their fiscal indicators. In addition, these variables may respond endogenously to an intervention (e.g. population size may increase or decrease as a result of an intervention) and impact political behavior. Thus, omitting the time-varying control variables may bias the coefficients of interest. In the empirical analysis we address this concern by accounting for both fiscal measures such as debt, deficit and taxes as well as outcome variables like income per capita and education achievements. In addition, we plan to employ a series of sensitivity analyses to check the robustness of our results. For example, we will examine whether the results are sensitive to the duration of intervention, softer forms of interventions such as removing the council members only and an appointed accountant.

Unlike most studies, the risk of reverse causality in our research design is rather low. It is unlikely that the removal of elected mayors is driven by political participation and vote choice. Nevertheless, we plan to explore the possibility of reverse causality by examining the relations between past voting turnout in national elections and the likelihood of summoned committee.

To examine the effect of a policy change or perceived discrimination on vote choice, we estimate the following regression:

\footnotetext{
${ }^{15}$ The standard errors are clustered at the municipality level.
} 
(2) Arab parties $_{i, t}=\alpha(\text { appointed committee })_{i, t}+\mathbf{Z}_{i, t} \boldsymbol{\beta}+\gamma_{t}+\delta_{i}+e_{i, t}$

where the dependent variable is measured by the share of votes (out of total votes) for the three main Arab parties in the national parliament (KNESET) in municipality $i$ at election year $\mathrm{t}$. As before, the appointed committee is a dummy variable that gets 1 if the authority in municipality $i$ is in the hands of appointed officials at the time of election $t$, and zero otherwise. $\mathbf{Z}_{i t}$ is a vector of time-varying municipality characteristics; $\boldsymbol{\gamma}_{t}$ is a fixed effect for each election year in the sample to control for general trends; $\boldsymbol{\delta}_{i}$ is a municipality fixed effect; $\alpha$ and the vector $\boldsymbol{\beta}$ are unknown parameters that would be estimated. Unobserved determinants of vote choice at the municipality level are represented by the error term, $e_{i t .}{ }^{16}$ We estimate the above model for Arab and Jewish municipalities separately, and as suggested in hypothesis $\mathrm{H} 3$, the estimated coefficient $\alpha$ should be positive in Arab localities.

Estimating equation (2) should be seen as a test of the suggested mechanism behind political participation. The Arab parties are key elite agents of Arab citizens in Israel who frame the mentioned policy change as an act of discrimination and provide organized resources to mobilize Arab voters to cast their protest in the ballot box. Thus, perceived discrimination that is associated with a policy change increases political engagement of Arab citizens in national elections. Estimating the impact of that policy change on vote choice of Jewish citizens could be seen as a placebo test. As stated in hypothesis H4, the expected coefficient $\alpha$ should be zero in Jewish municipalities.

\section{$\underline{4.2}$ Data}

The empirical analysis covers all municipalities that have data on all the variables that are used in this study. Thus, our research is based on 188 local municipalities in 2006 and 2009 elections and 195 in 2013 election out of 201, which is the total number of municipalities in Israel (Table 1). Regional municipalities were excluded due to lack of data on voter turnout and vote choice. ${ }^{17}$

\footnotetext{
${ }^{16}$ As before, we cluster the standard errors at the municipality level.

${ }^{17}$ Five Druz municipalities in the Golan Heights (Buq'ata, Majdal-Shams, Mas'ade, EinQinyye and Ghajar) as well as the municipality of Basma (an Arab municipality in the Galilei) are excluded in all three elections due to lack of data on voter turnout. In addition,
} 
We have merged data from two sources, The Interior Ministry and the Center for Research and Information at the Knesset to generate time series data on the timing and duration of appointing a summoned committee and an accountant in the years 2005-2013. This is our key independent variable. The total number of summoned committees that were appointed is 45 and the duration of intervention is more than 3 years on average during the period covered in this research (Table 1). Table 2 presents a detailed time line of the appointed committees for each municipality.

The data on actual average voter turnout (actual voters relative to eligible voters) in national election and the average voting share for Arab political parties (out of the total votes) in each municipality for the last three national elections in the years 2006, 2009 and 2013 is taken from the official Knesset website. This is also the source of data on other dependent variables such as the share of votes for the party of the Interior Minister, Prime Minister or Coalition Parties. As can be seen in Table 3, the average voter turnout in national elections is around $62 \%$ (this is a simple average across municipalities without attaching weights to each municipality according to its size in terms of population). The political participation in Jewish municipalities is higher as compared to Arab municipalities by 9 percentage points. A large share of Arab citizens vote for Arab parties while they gain only very negligible political support in Jewish municipalities (Table 3).

The Central Bureau of Statistics is the source of time-varying municipality characteristics such as the size of population in each municipality, demographic composition (the ratio of the population at the age of 65 or over to 20-64), average monthly wage, and education level (the share of eligible students for matriculation in $12^{\text {th }}$ grade). The socio-economic variables at the municipality level are computed for election years except for the last election for which we use 2012, that is the most recent available data.

\section{$\underline{4.3 \text { The results }}$}

seven other municipalities are excluded to avoid potential bias due to the effect of merged municipalities. These seven localities were merged in 2003 and a few years later were unmerged following considerable pressure by their residents (the seven municipalities are Ba'ana, Dir-el-Asad and Majd-el-Crum in 2008, Daliet-el-Carmel and Usefia in 2008, and Baqa-Al-Gharbiyye and Jat in 2010). 
It is worth illustrating the central results by looking at simple diff-in-diff tabulation. In Table 4 we compute simple averages of our two key dependent variables for two groups of municipalities: municipalities with an appointed committee either in 2009 or 2013 and municipalities without intervention. As can be seen, the voter turnout in national elections "before" the intervention in Arab municipalities is statistically the same in both groups of municipalities regardless of intervention. Comparing before and after (first diff) and between intervened and non-intervened Arab municipalities (second diff) we find that the intervention raises significantly voter turnout in national elections. The lower panel of Table 4 presents a significant increase also in voting share for Arab parties in Israeli parliament.

Table 5a shows the first main finding of this study using OLS regressions. In line with hypothesis H1, the effect of a summoned committee is negative on political participation in Jewish municipalities and positive in Arab municipalities. The effects are significant and relatively large in Arab municipalities. The removal of elected mayor who is replaced by an appointed committee tends to raise voter turnout by approximately 5 percentage points in Arab municipalities using the estimated coefficient. This suggests that our proxy (an appointed committee) for perceived group discrimination does mobilize Arab citizens to show up in the ballot boxes in larger numbers. As can be seen in Table 5b, Arab parties benefit from the higher voter turnout in national elections. The share of votes for Arab parties is higher by 4.4 percentage points but this coefficient is borderline significant. The estimated coefficient is quite large especially given that the vote share of Arab parties is already around $70 \%$ (Table 3). As expected, the "treatment" has no significant impact in terms of vote choice in Jewish towns and cities, which should be seen also as a placebo test. We have estimated the effect of a summoned committee on vote choice also in terms of vote share for the party of the Interior Ministry, Prime Minister and coalition parties and none come up consistently significant (the results are not reported here).

One may think that the results may reflect a compensation effect whereby those residents who are not allowed to cast their vote at local elections compensate themselves in national elections. The compensation hypothesis implies the same predicted effect in both Arabs and Jews which is not consistent with our results. Moreover, Ben-Bassat and Dahan (2012) show that this compensation hypothesis, 
which is very common with regard to Arab citizens, is unsupported empirically. In fact, they found that citizens in Arab municipalities who tend to vote at higher rates in local elections are also more likely to show up in the ballot boxes in national elections.

We deal here with the risk of selection bias that might stem from the fact that the Ministry of Interior has selected those municipalities based on their fiscal stress indicators which may be correlated with municipality characteristics. Indeed, the municipalities with summoned boards tend to be poorer (a lower average income) and smaller (a lower population size). As a result, the estimated effect may capture the differences between municipalities that were selected by central government rather than what the intervention does to political behavior. One more channel through which municipality characteristics may bias our results is their potential dynamics impact on attitudes. We address this risk by controlling for time-varying municipality characteristics such as socioeconomic status, education level, population size and its composition in addition to municipality fixed effects. Accounting for these municipality features also deals with the potential indirect effect that intervention may have on political behavior through its impact on individuals' resources like average income, as suggested by Verba et al (1995). ${ }^{18}$ Moreover, in our empirical setting the control group includes municipalities that have received "treatment" in previous or subsequent national elections which makes them more comparable to "treated" municipalities. As can be seen from Table 2, no municipality had an appointed committee in all three national elections that are covered in our study: 9 municipalities were ruled by an appointed committee during one national election only and 18 municipalities had such committees during two elections.

As can be seen in Tables $6 \mathrm{a}$ and $6 \mathrm{~b}$, all four hypotheses that are sketched above gain support after controlling for time-varying municipality characteristics. ${ }^{19}$ To make the comparison more meaningful, the first panel of Table $6 \mathrm{a}$ presents the estimated coefficient with observations that have complete data on municipality characteristics. The coefficient of an appointed committee is 0.036 with time-varying municipality

\footnotetext{
${ }^{18}$ Afriat and Dahan (2010) show that political participation in national elections in Israel is positively affected by the level of earnings.

${ }^{19}$ Using the actual net immigration to a certain municipality which is a common measure of municipality attractiveness in Israel instead of population size generates the same results (not reported here).
} 
characteristics and 0.042 without them. However, the effect of intervention on the vote share for Arab parties is smaller and less precisely estimated.

Nevertheless, we could not exclude the risk of selection on unobservable municipality characteristics. However, the selection of municipalities must be uncorrelated with the mentioned list of control variables including socioeconomic status, education level, population size and its composition in order to bias the results. The amount of selection on unobservables to selection on the observed explanatory variables would have to be high to mistrust our estimates (Altonji et al 2005). Our results gain more confidence given that the estimated coefficient remains almost the same as in Table 5 a.

In Tables $7 \mathrm{a}$ and $7 \mathrm{~b}$ we control for municipality fiscal distress indicators (taken from Israeli CBS) such as municipality debt relative to revenues and tax effectiveness measures (collected local taxes relative to local taxes that should have been collected) which were computed a year before election (the results are similar adding budget deficit relative to revenues but are not reported here). Note that according to the stated rules of the Ministry of Interior, the appointed committee is imposed in municipalities that cross certain thresholds of these three fiscal indicators. This list of additional control variables aims to capture the potential dynamic in residents' views regarding the intervention. Residents in municipalities with an appointed committee may first resent central government intervention but might change their minds based on actual fiscal outcomes. The attitudes toward central government intervention could be mitigated as a result of changes to the well-being of the residents in affected municipalities that may be attributed to the intervention. Table $7 \mathrm{a}$ shows that the "treatment" effect is significant and quantitatively important but somewhat smaller (0.055 as compared to 0.053$)$ when fiscal indicators are not controlled for. The estimated coefficient of intervention on Arab parties vote share remains almost the same (Table 7b).

Another seemingly source of bias could be the signal that the intervention itself may send to individuals regarding the economic distress of their municipality, that might affect negatively, for example, their expected permanent income. According to this suggestion, the change in political behavior may be the result of that signal rather than how public policy is perceived by the residents in intervened municipalities. Our 
empirical design addresses this concern by estimating the above model for Arab and Jewish municipalities separately to allow for an interaction effect between dominant/minority affiliation and perceived discrimination due to a particular policy change. The signaling story should have the same effect in both Arab and Jewish municipalities. In contrast, we found a positive coefficient in Arab localities but a negative one in Jewish municipalities, which is consistent with our hypotheses H1 and H2. Furthermore, our empirical design is immune to a general policy change that may affect uniformly the political behavior of all Arab citizens due to hostile political climate or following wide-ranging discriminatory policy like the proposal to downgrade Arabic from being an official language to a lower status. Such policy should evenly impact political participation in both types of Arab municipalities, which is inconsistent with our hypotheses and findings.

Our main results are not affected considerably after adding the duration of the appointed committee to our baseline regressions, expect that the estimated coefficient has higher standard deviation (Tables $8 \mathrm{a}$ and $8 \mathrm{~b}$ ). We do not control for socioeconomic characteristics in these regressions (and in the next regressions) to keep the number of "treated" observations as large as possible. Adding socio-economic variables to the robustness test generates the same general picture but with less precision and significance. The second robustness test is to see whether the results are sensitive to the inclusion of softer central government interventions such as appointing an accountant. The estimated coefficient of our key explanatory variable in tables $9 \mathrm{a}$ and $9 \mathrm{~b}$ remains significant and with almost the same magnitude after adding an appointed accountant to our baseline regression. An appointed accountant has no significant effect on voter turnout in national elections or vote share for Arab parties. The lower saliency of this sort of intervention, as compared to the high visibility of the removal of elected mayors, may explain the zero effect we find. Next, we limited our sample to the cases where both the elected mayor and the council members were removed (i.e. the dismissal of the elected council only has not been considered as an intervention or "treatment"). As before, the general picture that emerges is quite similar (Tables 10a and 10b), except that the estimated effect on Arab parties is less precise.

The risk that interior ministry has selected the policy tools (fiscal thresholds) based on political behavior is slim. Nevertheless, one may claim that the central government 
has targeted Arab municipalities according to their political participation and vote choice trends. According to this (unlikely) story the true intention of the government in launching this major economic program was curbing the upward trends in voter turnout and vote share for Arab parties in certain Arab municipalities. To address this potential bias that may result from reverse causality, we use the appointment of a summoned committee in 2007 as a dependent variable and the rate of change in voter turnout (or vote share for Arab parties) as the independent variable. The results in tables $11 \mathrm{a}$ and $11 \mathrm{~b}$ do not lend support to the reverse causality hypothesis.

\section{Conclusion}

We use a major policy intervention to study the effect of a biased policy that may convey a negative message about Arab minority group on their voting turnout and political preferences. To explore the link between policy and politics, we use the appointment of a summoned committee in a large number of Arab and Jewish municipalities in Israel which has been perceived as ethnically-biased by Arab minority (Arab citizens). We show that Arab voters in intervened municipalities are more likely to show up in the ballot boxes in national elections and they tend to vote more for Arab parties. In contrast, the political participation of Jewish citizens is lower in municipalities with appointed councils without a noticeable effect on vote choice. These important results are obtained using actual data on political participation and voting preferences in national elections. We believe the paper presents credible evidence that the intervention affected the attitudes of perceived discrimination which in turn have impacted political efficacy, and yet we acknowledge that the empirical examination reflects an estimation of a reduced-form relations between a public policy and political behavior assuming that internal and external political efficacy are the mediating factors.

The main estimated coefficients remain almost the same after controlling for municipality and election year fixed effects and a long list of time varying municipality characteristics, that may capture both residents' resources and taste such as socio-economic status as well as fiscal distress indicators that may represent changes in residents' attitudes. The robustness of our estimates reduces the risk that 
the results are driven by unobservable municipality characteristics. These results survive also a series of robustness tests such as adding the duration of intervention and other forms of intervention.

The findings of this paper have three important implications. First, it shows that policies have an impact on politics. The likelihood of various social groups to participate in national elections is affected by public policy. In particular, citizens of a certain social group who sense that the central government is implementing policies that discriminate against their political and economic interests chose to vote in larger numbers and vote disproportionally for parties that represent their social group. This result is consistent with mistrust-sense of political efficacy that was first suggested by Gamson (1968). Unlike the previous literature on mass policy feedback, the present paper shows that a negative message embodied in public policy may foster or dampen political participation, depending on social group affiliation. The subtle and interesting insight that emerges is that despite the increased feeling of mistrust among Arab citizens following certain types of public policy, they still play by the rules and believe that conventional political actions are the preferred means to change public policy.

Second, those who are pushing policies that are perceived as anti-minority should be aware that they have an impact on their own subsequent political power. We show here that the same policy generates higher political participation of a minority group and reduces the likelihood of members from the majority group to participate in national elections. Moreover, the citizens that are affiliated with the minority group vote more for minority-related parties. Thus, the interplay between social structure and the way public policy is perceived may affect the actual makeup of political preferences and therefore the outcome of national elections. The finding that policy actions may stimulate political engagement of certain groups and attenuate voter turnout of other social groups, thus changing the composition of political preferences expressed at the polls, becomes much more important as nation states continue to diversify in terms of their social structure.

Finally, this paper suggests that voter turnout may vary over time even if individual and institutional characteristics remain constant. Minority groups who face considerable adverse policy changes are expected to participate more in elections and 
strengthen their preexisting voting behavior for a given institutional environment and for the same individual traits. Therefore, explaining the large volatility in political participation and voting behavior over time must take into account the interaction between public policy and social structure. 


\section{Bibliography}

Afriat, Avishai, and Momi Dahan. (2010). "Socioeconomic bias in voting for the Knesset.” Israel Economic Review 8.1: 1-20.

Altonji, Joseph G., Todd E. Elder, and Christopher R. Taber. (2005). "Selection on Observed and Unobserved Variables: Assessing the Effectiveness of Catholic Schools.” Journal of Political Economy 113.1.

Austin, Sharon D. Wright, Richard T. Middleton, and Rachel Yon. (2012). "The Effect of Racial Group Consciousness on the Political Participation of African Americans and Black Ethnics in Miami-Dade County, Florida." Political Research Quarterly, 65(3): 629-641.

Beeri, Itai, and Fany Yuval. (2013). "New Localism and Neutralizing Local Government: Has Anyone Bothered Asking the Public for Its Opinion?" Journal of Public Administration Research and Theory: mut031.

Ben-Bassat, Avi and Momi Dahan. (2009). "The crises of localities in Israel: Efficiency versus representation," in Ben-Bassat, A., and M. Dahan (eds.), The Political Economics of the Municipalities in Israel, Jerusalem, Israel: The Israel Democracy Institute (in Hebrew), 15-91.

Ben-Bassat, Avi, and Momi Dahan. (2012). "Social identity and voting behavior." Public Choice 151.1-2: 193-214.

Ben-Bassat, Avi, Momi Dahan and Esteban F. Klor. (2016a). "Is Centralization a Solution to the Soft Budget Constraint Problem?" forthcoming in European Journal of Political Economy.

Ben Bassat, Avi, Momi Dahan, and Esteban F. Klor. (2016b). "Does Campaign Spending Affect Electoral Outcomes?” Electoral Studies 40 (December): 102-114.

Bobo, Lawrence, and Franklin D. Gilliam Jr. (1990). "Race, sociopolitical participation, and black empowerment." American Political Science Review 84: 377 393.

Brown, R. Khari, and Ronald E. Brown. (2003). "Faith and works: Church-based social capital resources and African American political activism." Social Forces 82.2: 617-641.

Bruch, Sarah K., Myra Marx Ferree, and Joe Soss. (2010). "From policy to polity democracy, paternalism, and the incorporation of disadvantaged citizens." American Sociological Review 75.2: 205-226. 
Campbell, Andrea. (2003). "Participatory Reactions to Policy Threats: Senior Citizens and the Defense of Social Security and Medicare." Political Behavior 25: 29-49.

Campbell, Andrea Louise. (2012). "Policy makes mass politics." Annual Review of Political Science 15: 333-351.

Cho, Wendy K. Tam, James G. Gimpel, and Tony Wu. (2006). "Clarifying the role of SES in political participation: Policy threat and Arab American mobilization." Journal of Politics 68.4: 977-991.

El-Taji, Maha T. (2008). Arab local authorities in Israel: Hamulas, nationalism and dilemmas of social change. Diss. University of Washington.

Feldman, Stanley, and Karen Stenner. (1997). "Perceived Threat and Authoritarianism." Political Psychology 18 (4): 741-70.

Finkel, Steven E. (1985). "Reciprocal effects of participation and political efficacy: A panel analysis.” American Journal of Political Science 4: 891-913.

Gamson, William A. (1968). Power and discontent. Vol. 124. Homewood, IL: Dorsey Press.

Gump, Brooks B. and James A. Kulik. (1997). "Stress, Affiliation and Emotional Contagion.” Journal of Personality and Social Psychology 72 (2): 305-19.

Harris, Fredrick C. (1994). "Something within: Religion as a mobilizer of AfricanAmerican political activism." Journal of Politics 56.01: 42-68.

Herman Tamar et al, Israeli Democracy Index 2013, Israel Democracy Institute.

Leighley, Jan E. (2001). Strength in numbers?: The political mobilization of racial and ethnic minorities. Princeton University Press.

Leighley, Jan E., and Jonathan Nagler. (2013). Who Votes Now?: Demographics, Issues, Inequality, and Turnout in the United States. Princeton University Press.

Logan, John R., Jennifer Darrah, and Sookhee Oh. (2012). "The impact of race and ethnicity, immigration and political context on participation in American electoral politics." Social Forces 90.3: 993-1022.

Lowenstein, George F., Elke U. Weber, Christopher K. Hsee, and Ned Welch. (2001). "Risk as Feelings." Psychological Bulletin 127 (2): 267-86. 
Marcus, George E., W. Russell Neuman, and Michael MacKuen. (2000). Affective Intelligence and Political Judgment. Chicago: University of Chicago Press.

Mettler, Suzanne. (2005). Soldiers to Citizens: The GI Bill and the Making of the Greatest Generation. New York: Oxford University Press.

Miller H. Arthur, Patricia Gurin, Gerald Gurin and Oksana Malanchuk. (1981). "Group consciousness and political participation." American Journal of Political Science 25(3): 494-511.

Miller, Joanne M., and Jon Krosnick. (2004). "Threat as a Motivator of Political Activism: A Field Experiment." Political Psychology 25 (4): 507-23.

Morrell, Michael E. (2003). "Survey and experimental evidence for a reliable and valid measure of internal political efficacy." Public Opinion Quarterly 67: 589-602.

Niemi, Richard G., Stephen C. Craig, and Franco Mattei. (1991). "Measuring internal political efficacy in the 1988 National Election Study." American Political Science Review 85.04: 1407-1413.

Pantoja, Adrian D., and Gary M. Segura. (2003). "Does Ethnicity Matter? Descriptive Representation in Legislatures and Political Alienation Among Latinos." Social Science Quarterly 84.2: 441-460.

Pantoja, Adrian D., Ricardo Ramirez, and Gary M. Segura. (2001). "Citizens by choice, voters by necessity: Patterns in political mobilization by naturalized Latinos." Political Research Quarterly 54.4: 729-750.

Pierson, Paul. (1993). "When effect becomes cause: Policy feedback and political change." World politics 45.04: 595-628.

Rosenstone, Steven, and John M. Hansen. (1993). "Mobilization, participation and democracy in America." New York: Macmillan.

Rudolph, Thomas J., Amy Gangl, and Dan Stevens. (2000). “The Effects of Efficacy and Emotions on Campaign Involvement.” Journal of Politics 62 (4): 1189-97.

Salamon, Lester M. and Stephen Van Evera. (1973). "Fear, Apathy and Discrimination: A Test of Three Explanations of Political Participation.” American Political Science Review 67 (4): 1288-1306.

Schachter, Stanley. (1959). The Psychology of Affiliation. Stanford, CA: Stanford University Press. 
Schattschneider, Elmer Eric. (1935). Politics, pressures and the tariff. New York: Prentice Hall.

Schildkraut, Deborah J. (2005). "The rise and fall of political engagement among Latinos: The role of identity and perceptions of discrimination." Political Behavior 27.3: 285-312.

Schneider, Anne, and Helen Ingram. (1993). "Social construction of target populations: Implications for politics and policy." American Political Science Review 87.02: 334-347.

Shingles, Richard D. (1981). "Black consciousness and political participation: The missing link.” American Political Science Review 75.01: 76-91.

Soss, Joe. (1999). "Lessons of welfare: Policy design, political learning, and political action." American Political Science Review 93.02: 363-380.

Soss, Joe, and Sanford F. Schram. (2007). "A public transformed? Welfare reform as policy feedback.” American Political Science Review 101.01: 111-127.

Tate, Katherine. (1991). "Black political participation in the 1984 and 1988 presidential elections.” American Political Science Review 85(4): 1159-1176.

Tate, Katherine, ed. (1994). From protest to politics: The new black voters in American elections. Harvard University Press.

Valentino, Nicholas A., et al. (2011). "Election night's alright for fighting: The role of emotions in political participation." Journal of Politics 73.01: 156-170.

Verba, Sidney, and Norman H. Nie. (1972). Participation in America: Political Democracy and Social Equality. Harper \& Row.

Verba, Sidney, Kay Lehman Schlozman, and Henry E. Brady. (1995). Voice and equality: Civic voluntarism in American politics. Vol. 4. Cambridge, MA: Harvard University Press.

Washington, Ebonya. (2006). "How black candidates affect voter turnout." The Quarterly Journal of Economics 121: 973-98.

Wilcox, Clyde, and Leopoldo Gomez. (1990). "Religion, group identification, and politics among American Blacks.” Sociology of Religion 51.3: 271-285. 
Table 1: The number of municipalities and intervention duration, by election and sector

\begin{tabular}{|c|c|c|c|c|c|}
\hline & \multirow{2}{*}{$\begin{array}{c}\text { All } \\
\text { municipalities }\end{array}$} & \multicolumn{2}{|c|}{$\begin{array}{c}\text { municipalities without a summon } \\
\text { board }\end{array}$} & \multicolumn{2}{|c|}{ municipalities with a summon board } \\
\hline & & Jews & Arabs & Jews & Arabs \\
\hline 2006 & 188 & 119 & 66 & $\begin{array}{c}1 \\
(0.39)\end{array}$ & $\begin{array}{c}2 \\
(0.38)\end{array}$ \\
\hline 2009 & 188 & 113 & 56 & $\begin{array}{c}7 \\
(2.10)\end{array}$ & $\begin{array}{c}12 \\
(1.80)\end{array}$ \\
\hline 2013 & 195 & 114 & 58 & $\begin{array}{c}6 \\
(5.37) \\
\end{array}$ & $\begin{array}{c}17 \\
(4.57)\end{array}$ \\
\hline Total & 571 & 346 & 180 & $\begin{array}{c}14 \\
(3.38)\end{array}$ & $\begin{array}{c}31 \\
(3.23)\end{array}$ \\
\hline
\end{tabular}

Source: Data provided by Michal Goldstein, Senior Director of the Department of Municipal Administration, at the Local Government Administration, Ministry of Interior and the manuscript: "The duration of Summon board", Research and Information Center, the Knesset, 2009.

Note: in parentheses are the number of years the summon board committee serves till the date of next Knesset elections. 
Table 2: Municipalities with a summon board, 2005-2013

\begin{tabular}{|c|c|c|c|c|c|c|c|c|c|c|}
\hline Municipality & 2004 & 2005 & $\begin{array}{c}2006 \\
28 / 3 / 06\end{array}$ & 2007 & 2008 & $\begin{array}{c}2009 \\
10 / 2 / 09\end{array}$ & 2010 & 2011 & 2012 & $\begin{array}{c}2013 \\
22 / 1 / 13\end{array}$ \\
\hline Abu Ghosh & & & & $\sqrt{ }$ & $\sqrt{ }$ & & & & & \\
\hline Ofakim & & & & $\sqrt{ }$ & $\sqrt{ }$ & $\sqrt{ }$ & $\sqrt{ }$ & $\sqrt{ }$ & $\sqrt{ }$ & $\sqrt{ }$ \\
\hline Ibillin & & $\sqrt{ }$ & $\sqrt{ }$ & $\sqrt{ }$ & $\sqrt{ }$ & $\sqrt{ }$ & $\sqrt{ }$ & & & \\
\hline Beit Jann & & $\sqrt{ }$ & $\sqrt{ }$ & $\sqrt{ }$ & $\sqrt{ }$ & & & & & \\
\hline Jisr al -Zarqa & & & & & & & & $\sqrt{ }$ & $\sqrt{ }$ & $\sqrt{ }$ \\
\hline Daburiya & & & & $\sqrt{ }$ & $\sqrt{ }$ & $\sqrt{ }$ & $\sqrt{ }$ & $\sqrt{ }$ & $\sqrt{ }$ & $\sqrt{ }$ \\
\hline Zemer & & & & $\sqrt{ }$ & $\sqrt{ }$ & $\sqrt{ }$ & $\sqrt{ }$ & $\sqrt{ }$ & $\sqrt{ }$ & $\sqrt{ }$ \\
\hline Zarzir & & & & & & & $\sqrt{ }$ & $\sqrt{ }$ & $\sqrt{ }$ & $\sqrt{ }$ \\
\hline Hadera & & & & & & & $\sqrt{ }$ & $\sqrt{ }$ & $\sqrt{ }$ & $\sqrt{ }$ \\
\hline Tuba Zangariyye & & & & $\sqrt{ }$ & $\sqrt{ }$ & $\sqrt{ }$ & $\sqrt{ }$ & $\sqrt{ }$ & $\sqrt{ }$ & $\sqrt{ }$ \\
\hline Taybeh & & & & $\sqrt{ }$ & $\sqrt{ }$ & $\sqrt{ }$ & $\sqrt{ }$ & $\sqrt{ }$ & $\sqrt{ }$ & $\sqrt{ }$ \\
\hline Tira & & & & $\sqrt{ }$ & $\sqrt{ }$ & & & & & \\
\hline Tamra & & & & & & $1 / 12 / 09$ & $\sqrt{ }$ & $\sqrt{ }$ & $\sqrt{ }$ & $\sqrt{ }$ \\
\hline Turan & & & & $\sqrt{ }$ & $\sqrt{ }$ & $\sqrt{ }$ & $\sqrt{ }$ & $\sqrt{ }$ & $\sqrt{ }$ & $\sqrt{ }$ \\
\hline Yanuh-Jat & & & & & & $1 / 12 / 09$ & $\sqrt{ }$ & $\sqrt{ }$ & $\sqrt{ }$ & $\sqrt{ }$ \\
\hline Yesod Hamala & & & & $\sqrt{ }$ & $\sqrt{ }$ & $\sqrt{ }$ & $\sqrt{ }$ & $\sqrt{ }$ & $\sqrt{ }$ & $\sqrt{ }$ \\
\hline Yeruham & & $\sqrt{ }$ & $\sqrt{ }$ & $\sqrt{ }$ & $\sqrt{ }$ & $\sqrt{ }$ & $\sqrt{ }$ & & & \\
\hline Yarqa & & & & $\sqrt{ }$ & $\sqrt{ }$ & $\sqrt{ }$ & $\sqrt{ }$ & $\sqrt{ }$ & $\sqrt{ }$ & $\sqrt{ }$ \\
\hline Kefar Kana & & & & $\sqrt{ }$ & $\sqrt{ }$ & $\sqrt{ }$ & $\sqrt{ }$ & $\sqrt{ }$ & $\sqrt{ }$ & $\sqrt{ }$ \\
\hline Kafr Manda & & & & $\sqrt{ }$ & $\sqrt{ }$ & $\sqrt{ }$ & $\sqrt{ }$ & $\sqrt{ }$ & $\sqrt{ }$ & $\sqrt{ }$ \\
\hline Lod & & & & $\sqrt{ }$ & $\sqrt{ }$ & $\sqrt{ }$ & $\sqrt{ }$ & $\sqrt{ }$ & $\sqrt{ }$ & $\sqrt{ }$ \\
\hline Migdal & & & & $\sqrt{ }$ & $\sqrt{ }$ & $\sqrt{ }$ & $\sqrt{ }$ & $\sqrt{ }$ & $\sqrt{ }$ & $\sqrt{ }$ \\
\hline Miilya & & & & $\sqrt{ }$ & $\sqrt{ }$ & & & $\sqrt{ }$ & $\sqrt{ }$ & $\sqrt{ }$ \\
\hline Maale Iron & & & $1 / 11 / 06$ & $\sqrt{ }$ & $\sqrt{ }$ & $\sqrt{ }$ & $\sqrt{ }$ & $\sqrt{ }$ & $\sqrt{ }$ & $\sqrt{ }$ \\
\hline Mitzpe Ramon & & & & $\sqrt{ }$ & $\sqrt{ }$ & & & & & \\
\hline Nahf & & & $27 / 9 / 06$ & $\sqrt{ }$ & $\sqrt{ }$ & $\sqrt{ }$ & $\sqrt{ }$ & $\sqrt{ }$ & $\sqrt{ }$ & $\sqrt{ }$ \\
\hline Arad & & & & $\sqrt{ }$ & $\sqrt{ }$ & $\sqrt{ }$ & $\sqrt{ }$ & & & \\
\hline Arara & & & & & & $1 / 12 / 09$ & $\sqrt{ }$ & $\sqrt{ }$ & $\sqrt{ }$ & $\sqrt{ }$ \\
\hline Arara Banegev & & & & & $\sqrt{ }$ & $\sqrt{ }$ & $\sqrt{ }$ & $\sqrt{ }$ & $\sqrt{ }$ & $\sqrt{ }$ \\
\hline Ktzir Harish & & & $1 / 10 / 06$ & $\sqrt{ }$ & $\sqrt{ }$ & $\sqrt{ }$ & $\sqrt{ }$ & $\sqrt{ }$ & $\sqrt{ }$ & $\sqrt{ }$ \\
\hline Total & 0 & 3 & 6 & 23 & 24 & 22 & 24 & 23 & 23 & 23 \\
\hline Total, at the time of elections & $\mathbf{0}$ & 3 & 3 & 23 & 24 & 19 & 24 & 23 & 23 & 23 \\
\hline
\end{tabular}

Source: see table 1 .

Note: Merged municipalities which were later separated were excluded from the statistical analysis. 
Table 3: Voter turnout and voting share for Arab parties in national elections

\begin{tabular}{|c|c|c|c|c|c|c|}
\hline & \multicolumn{3}{|c|}{ Voter turnout (\%) } & \multicolumn{3}{|c|}{ Voting share for Arab parties (\%) } \\
\hline & $\begin{array}{c}\text { All } \\
\text { Muni. }\end{array}$ & $\begin{array}{l}\text { Jewish } \\
\text { Muni. }\end{array}$ & $\begin{array}{l}\text { Arab } \\
\text { Muni. }\end{array}$ & $\begin{array}{c}\text { All } \\
\text { Muni. }\end{array}$ & $\begin{array}{l}\text { Jewish } \\
\text { Muni. }\end{array}$ & $\begin{array}{l}\text { Arab } \\
\text { Muni. }\end{array}$ \\
\hline 2006 & $\begin{array}{c}62.1 \\
(11.1)\end{array}$ & $\begin{array}{l}64.0 \\
(9.2)\end{array}$ & $\begin{array}{c}58.6 \\
(13.1)\end{array}$ & $\begin{array}{c}24.4 \\
(34.9)\end{array}$ & $\begin{array}{c}0.8 \\
(3.1)\end{array}$ & $\begin{array}{c}65.9 \\
(25.5)\end{array}$ \\
\hline 2009 & $\begin{array}{c}61.0 \\
(12.3)\end{array}$ & $\begin{array}{l}65.3 \\
(8.5)\end{array}$ & $\begin{array}{c}53.5 \\
(14.2)\end{array}$ & $\begin{array}{c}28.0 \\
(39.7)\end{array}$ & $\begin{array}{c}1.0 \\
(3.2)\end{array}$ & $\begin{array}{c}75.7 \\
(27.8)\end{array}$ \\
\hline 2013 & $\begin{array}{c}64.0 \\
(11.4) \\
\end{array}$ & $\begin{array}{r}68.2 \\
(9.1) \\
\end{array}$ & $\begin{array}{c}57.3 \\
(11.6) \\
\end{array}$ & $\begin{array}{c}27.6 \\
(37.8) \\
\end{array}$ & $\begin{array}{c}1.0 \\
(3.5) \\
\end{array}$ & $\begin{array}{c}70.1 \\
(27.4) \\
\end{array}$ \\
\hline Average & 62.4 & 65.8 & 56.5 & 26.7 & 1.0 & 70.5 \\
\hline
\end{tabular}


Table 4: Illustrating the effects: Diff-in-diff

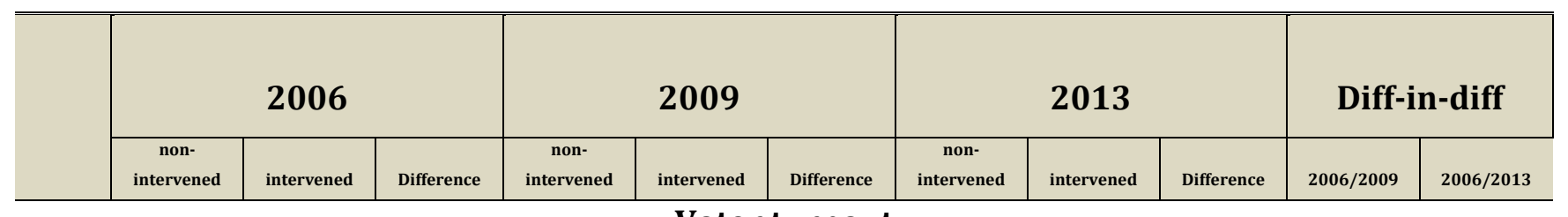

Voter turnout

\begin{tabular}{|c|c|c|c|c|c|c|c|c|c|c|c|}
\hline Arab & $\begin{array}{c}0.594 \\
(0.019) \\
\end{array}$ & $\begin{array}{c}0.563 \\
(0.029) \\
\end{array}$ & $\begin{array}{c}-0.031 \\
(0.035) \\
\end{array}$ & $\begin{array}{c}0.529 \\
(0.021) \\
\end{array}$ & $\begin{array}{c}0.554 \\
(0.030) \\
\end{array}$ & $\begin{array}{c}0.026 \\
(0.037) \\
\end{array}$ & $\begin{array}{c}0.570 \\
(0.017) \\
\end{array}$ & $\begin{array}{c}0.581 \\
(0.025) \\
\end{array}$ & $\begin{array}{c}0.011 \\
(0.030) \\
\end{array}$ & $\begin{array}{c}\mathbf{0 . 0 5 7} * * * \\
(0.021) \\
\end{array}$ & $\begin{array}{c}\mathbf{0 . 0 4 2} * * \\
(0.021) \\
\end{array}$ \\
\hline Jewish & $\begin{array}{c}0.645 \\
(0.009)\end{array}$ & $\begin{array}{c}0.581 \\
(0.022)\end{array}$ & $\begin{array}{c}-\mathbf{0 . 0 6 3} \\
(0.024)\end{array}$ & $\begin{array}{c}0.657 \\
(0.008)\end{array}$ & $\begin{array}{c}0.595 \\
(0.019)\end{array}$ & $\begin{array}{c}-\mathbf{0 . 0 6 2} \mathbf{2}^{* * *} \\
(0.021)\end{array}$ & $\begin{array}{c}0.687 \\
(0.009)\end{array}$ & $\begin{array}{c}0.618 \\
(0.022)\end{array}$ & $\begin{array}{c}-\mathbf{0 . 0 6 8} * * * \\
(0.023)\end{array}$ & $\begin{array}{c}0.001 \\
(0.007)\end{array}$ & $\begin{array}{c}-0.005 \\
(0.007)\end{array}$ \\
\hline All. & $\begin{array}{c}0.629 \\
(0.009) \\
\end{array}$ & $\begin{array}{c}0.568 \\
(0.021) \\
\end{array}$ & $\begin{array}{c}-\mathbf{0 . 0 6 1} \\
(0.023) \\
\end{array}$ & $\begin{array}{c}0.617 \\
(0.010) \\
\end{array}$ & $\begin{array}{c}0.567 \\
(0.022) \\
\end{array}$ & $\begin{array}{c}-\mathbf{0 . 0 5 0} * * \\
(0.024) \\
\end{array}$ & $\begin{array}{c}0.651 \\
(0.009) \\
\end{array}$ & $\begin{array}{c}0.593 \\
(0.018) \\
\end{array}$ & $\begin{array}{c}-\mathbf{0 . 0 5 8} * * * \\
(0.020)\end{array}$ & $\begin{array}{c}0.010 \\
(0.013)\end{array}$ & $\begin{array}{c}0.003 \\
(0.013)\end{array}$ \\
\hline \multicolumn{12}{|c|}{ Vote share for Arab parties } \\
\hline Arab & $\begin{array}{c}0.663 \\
(0.036)\end{array}$ & $\begin{array}{c}0.648 \\
(0.062)\end{array}$ & $\begin{array}{l}-0.015 \\
(0.072)\end{array}$ & $\begin{array}{c}0.743 \\
(0.040)\end{array}$ & $\begin{array}{c}0.794 \\
(0.064)\end{array}$ & $\begin{array}{c}0.051 \\
(0.075)\end{array}$ & $\begin{array}{c}0.701 \\
(0.040)\end{array}$ & $\begin{array}{c}0.732 \\
(0.054)\end{array}$ & $\begin{array}{c}0.032 \\
(0.068)\end{array}$ & $\begin{array}{c}\mathbf{0 . 0 6 6 * *} \\
(0.030)\end{array}$ & $\begin{array}{c}\mathbf{0 . 0 4 7}^{*} \\
(0.028)\end{array}$ \\
\hline Jewish & $\begin{array}{c}0.008 \\
(0.003) \\
\end{array}$ & $\begin{array}{c}0.019 \\
(0.014) \\
\end{array}$ & $\begin{array}{c}0.011 \\
(0.014) \\
\end{array}$ & $\begin{array}{c}0.009 \\
(0.003) \\
\end{array}$ & $\begin{array}{c}0.021 \\
(0.015) \\
\end{array}$ & $\begin{array}{c}0.012 \\
(0.015) \\
\end{array}$ & $\begin{array}{c}0.009 \\
(0.003) \\
\end{array}$ & $\begin{array}{c}0.024 \\
(0.018) \\
\end{array}$ & $\begin{array}{c}0.015 \\
(0.019) \\
\end{array}$ & $\begin{array}{c}0.001 \\
(0.001) \\
\end{array}$ & $\begin{array}{c}0.003 \\
(0.005) \\
\end{array}$ \\
\hline All. & $\begin{array}{c}0.210 \\
(0.026)\end{array}$ & $\begin{array}{c}0.454 \\
(0.072)\end{array}$ & $\begin{array}{c}0.244^{* * *} \\
(0.076)\end{array}$ & $\begin{array}{c}0.236 \\
(0.030)\end{array}$ & $\begin{array}{c}0.557 \\
(0.083)\end{array}$ & $\begin{array}{c}0.321^{* * *} \\
(0.088)\end{array}$ & $\begin{array}{c}0.223 \\
(0.028) \\
\end{array}$ & $\begin{array}{c}0.514 \\
(0.075)\end{array}$ & $\begin{array}{c}\mathbf{0 . 2 9 2} \\
(0.000)\end{array}$ & $\begin{array}{c}\mathbf{0 . 0 7 6} \text { *** }^{* *} \\
(0.023)\end{array}$ & $\begin{array}{c}\mathbf{0 . 0 4 7}^{* *} \\
(0.019) \\
\end{array}$ \\
\hline
\end{tabular}

Note: Municipalities with an appointed committee either in 2009 or 2013 are defined as "intervened". According to that definition, there are 18 Arab municipalities with intervention and 50 without. There are 8 Jewish municipalities with intervention and 112 without.

* Significance level of $10 \%{ }^{* *}$ significance level of $5 \%{ }^{* * *}$ significance level of $1 \%$. Clustered standard errors are in parentheses. 
Table 5a: The effect of a summon board on voter turnout in national elections

\begin{tabular}{lccc}
\hline \hline \multicolumn{1}{c}{ Variable } & $\begin{array}{c}\text { All } \\
\text { Municipalities }\end{array}$ & $\begin{array}{c}\text { Jewish } \\
\text { Municipalities }\end{array}$ & $\begin{array}{c}\text { Arab } \\
\text { Municipalities }\end{array}$ \\
\hline $\begin{array}{l}\text { A summon board served at the time of Knesset } \\
\text { election }\end{array}$ & 0.016 & $\mathbf{- 0 . 0 1 0 * *}^{* *}$ & $\mathbf{0 . 0 4 9 * * *}$ \\
& $(0.011)$ & $(0.004)$ & $(0.016)$ \\
\hline Adjusted R-Squared & 0.15 & 0.65 & 0.21 \\
Observations & 571 & 360 & 211 \\
Observations with a summon board & 45 & 14 & 31 \\
Number of municipalities & 195 & 120 & 75 \\
\hline
\end{tabular}

Notes:

* Regressions were estimated using OLS with municipality and election year fixed effects. * significance level of $10 \%{ }^{* *}$ significance level of $5 \%{ }^{* * *}$ significance level of $1 \%$. Clustered standard errors are in parentheses.

A merger of several municipalities is considered as a unified municipality after the time of the merger. Merged municipalities which later were separated were excluded.

Table 5b: The effect of a summon board on voting share for Arabs parties

\begin{tabular}{lccc}
\hline \hline \multicolumn{1}{c}{ Variable } & $\begin{array}{c}\text { All } \\
\text { Municipalities }\end{array}$ & $\begin{array}{c}\text { Jewish } \\
\text { Municipalities }\end{array}$ & $\begin{array}{c}\text { Arab } \\
\text { Municipalities }\end{array}$ \\
\hline $\begin{array}{l}\text { A summon board served at the time of Knesset } \\
\text { election }\end{array}$ & $\mathbf{0 . 0 4 1 * *}$ & 0.001 & $\mathbf{0 . 0 4 4 *}$ \\
& $(0.017)$ & $(0.003)$ & $(0.022)$ \\
\hline Adjusted R-Squared & 0.15 & 0.05 & 0.34 \\
Observations & 571 & 360 & 211 \\
Observations with a summon board & 45 & 14 & 31 \\
Number of municipalities & 195 & 120 & 75 \\
\hline
\end{tabular}

Notes: see table 5 a. 
Table 6a: The effect of a summon board on voter turnout in national elections Sensitivity analysis: adding municipality socioeconomic characteristics

\begin{tabular}{|c|c|c|c|c|c|c|}
\hline \multirow[b]{2}{*}{ Variable } & \multicolumn{3}{|c|}{ (1) } & \multicolumn{3}{|c|}{$(2)$} \\
\hline & $\begin{array}{c}\text { All } \\
\text { Muni. }\end{array}$ & $\begin{array}{l}\text { Jews } \\
\text { Muni. }\end{array}$ & $\begin{array}{l}\text { Arabs } \\
\text { Muni. }\end{array}$ & $\begin{array}{l}\text { All } \\
\text { Muni. }\end{array}$ & $\begin{array}{l}\text { Jews } \\
\text { Muni. }\end{array}$ & $\begin{array}{l}\text { Arabs } \\
\text { Muni. }\end{array}$ \\
\hline \multirow{2}{*}{$\begin{array}{l}\text { A summon board served at the time of } \\
\text { Knesset election }\end{array}$} & 0.013 & -0.007 & $0.042 * *$ & 0.010 & -0.008 & $0.036 * *$ \\
\hline & $(0.012)$ & $(0.004)$ & $(0.016)$ & $(0.011)$ & $(0.006)$ & $(0.015)$ \\
\hline \multirow[t]{2}{*}{ The ratio of $65+$ to $20-64$ Population } & & & & 0.043 & -0.026 & -0.014 \\
\hline & & & & $(0.149)$ & $(0.078)$ & $(0.611)$ \\
\hline \multirow[t]{2}{*}{ Log Population } & & & & -0.006 & $0.067 * * *$ & -0.018 \\
\hline & & & & $(0.054)$ & $(0.016)$ & $(0.145)$ \\
\hline \multirow[t]{2}{*}{$\begin{array}{l}\text { Log average monthly wage of } \\
\text { employees }\end{array}$} & & & & $0.202 * * *$ & $0.092 * * *$ & $0.386 * * *$ \\
\hline & & & & $(0.071)$ & $(0.029)$ & $(0.135)$ \\
\hline \multirow[t]{2}{*}{$\begin{array}{l}\text { Rate of eligibility for matriculation } \\
\text { among 12th grade students }\end{array}$} & & & & -0.002 & -0.002 & -0.045 \\
\hline & & & & $(0.044)$ & $(0.022)$ & $(0.060)$ \\
\hline Adjusted R-Squared & 0.13 & 0.65 & 0.17 & 0.16 & 0.71 & 0.22 \\
\hline Observations & 517 & 323 & 194 & 517 & 323 & 194 \\
\hline Observations with a summon board & 38 & 9 & 29 & 38 & 9 & 29 \\
\hline $\begin{array}{l}\text { Number of municipalities included in } \\
\text { the regression }\end{array}$ & 184 & 111 & 73 & 184 & 111 & 73 \\
\hline
\end{tabular}

Notes: see table $5 \mathrm{a}$ 
Table 6b: The effect of a summon board on voting share for Arabs parties Sensitivity analysis: adding municipality socioeconomic characteristics

\begin{tabular}{|c|c|c|c|c|c|c|}
\hline \multirow[b]{2}{*}{ Variable } & \multicolumn{3}{|c|}{$(1)$} & \multicolumn{3}{|c|}{$(2)$} \\
\hline & $\begin{array}{c}\text { All } \\
\text { Muni. }\end{array}$ & $\begin{array}{l}\text { Jews } \\
\text { Muni. }\end{array}$ & $\begin{array}{l}\text { Arabs } \\
\text { Muni. }\end{array}$ & $\begin{array}{c}\text { All } \\
\text { Muni. }\end{array}$ & $\begin{array}{l}\text { Jews } \\
\text { Muni. }\end{array}$ & $\begin{array}{l}\text { Arabs } \\
\text { Muni. }\end{array}$ \\
\hline \multirow[t]{2}{*}{$\begin{array}{l}\text { A summon board served at the time of } \\
\text { Knesset election }\end{array}$} & $0.043 * * *$ & 0.003 & $0.039 * *$ & $0.037 * * *$ & 0.003 & $0.029 *$ \\
\hline & $(0.013)$ & $(0.004)$ & $(0.016)$ & $(0.012)$ & $(0.004)$ & $(0.015)$ \\
\hline \multirow[t]{2}{*}{ The ratio of $65+$ to $20-64$ Population } & & & & $0.339 * *$ & -0.025 & 0.763 \\
\hline & & & & $(0.153)$ & $(0.025)$ & $(0.730)$ \\
\hline \multirow[t]{2}{*}{ Log Population } & & & & 0.023 & -0.008 & 0.097 \\
\hline & & & & $(0.044)$ & $(0.006)$ & $(0.150)$ \\
\hline \multirow[t]{2}{*}{ Log average monthly wage of employees } & & & & $0.149 * *$ & -0.005 & $0.354 * *$ \\
\hline & & & & $(0.067)$ & $(0.006)$ & $(0.152)$ \\
\hline \multirow[t]{2}{*}{$\begin{array}{l}\text { Rate of eligibility for matriculation among } \\
12 \text { th grade students }\end{array}$} & & & & -0.062 & $-0.010 * *$ & 0.003 \\
\hline & & & & $(0.046)$ & $(0.005)$ & $(0.073)$ \\
\hline Adjusted R-Squared & 0.16 & 0.06 & 0.33 & 0.19 & 0.09 & 0.37 \\
\hline Observations & 517 & 323 & 194 & 517 & 323 & 194 \\
\hline Observations with a summon board & 38 & 9 & 29 & 38 & 9 & 29 \\
\hline $\begin{array}{l}\text { Number of municipalities included in the } \\
\text { regression }\end{array}$ & 184 & 111 & 73 & 184 & 111 & 73 \\
\hline
\end{tabular}

Notes: see table 5a 
Table 7a: The effect of a summon board on voter turnout in national elections Sensitivity analysis: adding municipality fiscal indicators

\begin{tabular}{|c|c|c|c|c|c|c|}
\hline \multirow[b]{2}{*}{ Variable } & \multicolumn{3}{|c|}{$(1)$} & \multicolumn{3}{|c|}{$(2)$} \\
\hline & $\begin{array}{c}\text { All } \\
\text { Muni. }\end{array}$ & $\begin{array}{l}\text { Jews } \\
\text { Muni. }\end{array}$ & $\begin{array}{l}\text { Arabs } \\
\text { Muni. }\end{array}$ & $\begin{array}{c}\text { All } \\
\text { Muni. }\end{array}$ & $\begin{array}{c}\text { Jews } \\
\text { Muni. }\end{array}$ & $\begin{array}{l}\text { Arabs } \\
\text { Muni. }\end{array}$ \\
\hline $\begin{array}{l}\text { A summon board served at the time of } \\
\text { Knesset election }\end{array}$ & $\begin{array}{l}0.019 \\
(0.012)\end{array}$ & $\begin{array}{l}\mathbf{- 0 . 0 0 9 * *} \\
(0.004)\end{array}$ & $\begin{array}{l}\mathbf{0 . 0 5 5} * * * \\
(0.017)\end{array}$ & $\begin{array}{l}\mathbf{0 . 0 2 2} * \\
(0.012)\end{array}$ & $\begin{array}{c}-\mathbf{- 0 . 0 1 4} * * * \\
(0.005)\end{array}$ & $\begin{array}{c}\mathbf{0 . 0 5 3} * * * \\
(0.017)\end{array}$ \\
\hline Debt (as a share of revenues) & & & & $\begin{array}{l}-0.008 \\
(0.018)\end{array}$ & $\begin{array}{l}\mathbf{0 . 0 2 1} * * \\
(0.010)\end{array}$ & $\begin{array}{l}-0.007 \\
(0.021)\end{array}$ \\
\hline Budget deficit (as a share of revenues) & & & & & & \\
\hline Tax effectiveness & & & & $\begin{array}{l}-0.013 \\
(0.031)\end{array}$ & $\begin{array}{c}0.011 \\
(0.020)\end{array}$ & $\begin{array}{c}0.018 \\
(0.038)\end{array}$ \\
\hline Adjusted R-Squared & 0.15 & 0.66 & 0.21 & 0.15 & 0.67 & 0.21 \\
\hline Observations & 527 & 334 & 193 & 527 & 334 & 193 \\
\hline Observations with a summon board & 42 & 13 & 29 & 42 & 13 & 29 \\
\hline $\begin{array}{l}\text { Number of municipalities included in the } \\
\text { regression }\end{array}$ & 192 & 119 & 73 & 192 & 119 & 73 \\
\hline
\end{tabular}

Notes: see table 5a 
Table 7b: The effect of a summon board on voting share for Arabs parties Sensitivity analysis: adding municipality fiscal indicators

\begin{tabular}{|c|c|c|c|c|c|c|}
\hline \multirow[b]{2}{*}{ Variable } & \multicolumn{3}{|c|}{$(1)$} & \multicolumn{3}{|c|}{$(2)$} \\
\hline & $\begin{array}{c}\text { All } \\
\text { Muni. }\end{array}$ & $\begin{array}{l}\text { Jews } \\
\text { Muni. }\end{array}$ & $\begin{array}{l}\text { Arabs } \\
\text { Muni. }\end{array}$ & $\begin{array}{c}\text { All } \\
\text { Muni. }\end{array}$ & $\begin{array}{l}\text { Jews } \\
\text { Muni. }\end{array}$ & $\begin{array}{l}\text { Arabs } \\
\text { Muni. }\end{array}$ \\
\hline \multirow[t]{2}{*}{$\begin{array}{l}\text { A summon board served at the time of } \\
\text { Knesset election }\end{array}$} & $0.042 * *$ & 0.002 & $0.047 *$ & $0.042 * *$ & 0.002 & $0.050 *$ \\
\hline & $(0.018)$ & $(0.003)$ & $(0.024)$ & $(0.024)$ & $(0.003)$ & $(0.025)$ \\
\hline \multirow[t]{2}{*}{ Debt (as a share of revenues) } & & & & -0.008 & 0.005 & -0.004 \\
\hline & & & & $(0.027)$ & $(0.007)$ & $(0.036)$ \\
\hline \multirow[t]{2}{*}{$\begin{array}{l}\text { Budget deficit (as a share of } \\
\text { revenues) }\end{array}$} & & & & 0.030 & -0.011 & 0.049 \\
\hline & & & & $(0.035)$ & $(0.013)$ & $(0.036)$ \\
\hline \multirow[t]{2}{*}{ Tax effectiveness } & & & & -0.019 & -0.006 & -0.049 \\
\hline & & & & $(0.050)$ & $(0.004)$ & $(0.065)$ \\
\hline Adjusted R-Squared & 0.15 & 0.06 & 0.33 & 0.15 & 0.06 & 0.33 \\
\hline Observations & 520 & 329 & 191 & 520 & 329 & 191 \\
\hline Observations with a summon board & 41 & 13 & 28 & 41 & 13 & 28 \\
\hline $\begin{array}{l}\text { Number of municipalities included in } \\
\text { the regression }\end{array}$ & 191 & 118 & 73 & 191 & 118 & 73 \\
\hline
\end{tabular}

Notes: see table $5 \mathrm{a}$ 
Table 8a: The effect of a summon board on voter turnout in national elections Sensitivity analysis: adding the duration of the summon board committee

\begin{tabular}{lccc}
\hline \hline \multicolumn{1}{c}{ Variable } & $\begin{array}{c}\text { All } \\
\text { Municipalities }\end{array}$ & $\begin{array}{c}\text { Jewish } \\
\text { Municipalities }\end{array}$ & $\begin{array}{c}\text { Arab } \\
\text { Municipalities }\end{array}$ \\
\hline $\begin{array}{l}\text { A summon board served at the time of Knesset } \\
\text { election }\end{array}$ & $\mathbf{0 . 0 3 3}^{* *}$ & -0.008 & $\mathbf{0 . 0 6 6 ^ { * * * }}$ \\
& $(0.016)$ & $(0.009)$ & $(0.022)$ \\
$\begin{array}{l}\text { Duration of summon board committee service } \\
\text { (month) }\end{array}$ & $\mathbf{- 0 . 0 0 0 ^ { * }}$ & -0.000 & -0.000 \\
& $(0.000)$ & $(0.000)$ & $(0.000)$ \\
\hline Adjusted R-Squared & 0.15 & 0.65 & 0.21 \\
Observations & 571 & 360 & 211 \\
Observations with a summon board & 45 & 14 & 31 \\
Number of municipalities & 195 & 120 & 75 \\
\hline Notes: see taba & & & \\
\hline
\end{tabular}

Notes: see table $5 a$.

Table 8b: The effect of a summon board on voting share for Arabs parties Sensitivity analysis: adding the duration of the summon board committee

\begin{tabular}{lccc}
\hline \hline \multicolumn{1}{c}{ Variable } & $\begin{array}{c}\text { All } \\
\text { Municipalities }\end{array}$ & $\begin{array}{c}\text { Jewish } \\
\text { Municipalities }\end{array}$ & $\begin{array}{c}\text { Arab } \\
\text { Municipalities }\end{array}$ \\
\hline $\begin{array}{l}\text { A summon board served at the time of Knesset } \\
\text { election }\end{array}$ & $\mathbf{0 . 0 5 2 ^ { * * }}$ & -0.002 & 0.052 \\
& $(0.026)$ & $(0.002)$ & $(0.033)$ \\
$\begin{array}{l}\text { Duration of summon board committee serveic } \\
\text { (month) }\end{array}$ & -0.000 & 0.000 & -0.000 \\
& $(0.000)$ & $(0.000)$ & $(0.001)$ \\
\hline Adjusted R-Squared & 0.15 & 0.06 & 0.34 \\
Observations & 571 & 360 & 211 \\
Observations with a summon board & 45 & 14 & 31 \\
Number of municipalities & 195 & 120 & 75 \\
\hline
\end{tabular}

Notes: see table $5 a$. 
Table 9a: The effect of a summon board on voter turnout in national elections

Sensitivity analysis: adding an appointed accountant

\begin{tabular}{lccc}
\hline \hline \multicolumn{1}{c}{ Variable } & $\begin{array}{c}\text { All } \\
\text { Municipalities }\end{array}$ & $\begin{array}{c}\text { Jewish } \\
\text { Municipalities }\end{array}$ & $\begin{array}{c}\text { Arab } \\
\text { Municipalities }\end{array}$ \\
\hline $\begin{array}{l}\text { A summon board served at the time of } \\
\text { Knesset election }\end{array}$ & 0.017 & $\mathbf{- 0 . 0 1 1 * * *}$ & $\mathbf{0 . 0 4 9 * * *}$ \\
& $(0.012)$ & $(0.004)$ & $(0.016)$ \\
With an appointed accountant at the time of & -0.011 & $\mathbf{- 0 . 0 0 9 * *}$ & 0.001 \\
Knesset election & $(0.008)$ & $(0.004)$ & $(0.015)$ \\
& 0.15 & 0.65 & 0.20 \\
\hline Adjusted R-Squared & 571 & 360 & 211 \\
Observations & 45 & 14 & 31 \\
Observations with a summon board & 185 & 47 & 138 \\
Observations with an appointed accountant & 34 & 8 & 26 \\
Observations with a summon board and an & 195 & 120 & 75 \\
appointed accountant & & & \\
Number of municipalities & & & \\
\hline
\end{tabular}

Notes: see table $5 a$.

Table 9b: The effect of a summon board on voting share for Arabs parties

Sensitivity analysis: adding an appointed accountant

\begin{tabular}{lccc}
\hline \hline \multicolumn{1}{c}{ Variable } & $\begin{array}{c}\text { All } \\
\text { Municipalities }\end{array}$ & $\begin{array}{c}\text { Jewish } \\
\text { Municipalities }\end{array}$ & $\begin{array}{c}\text { Arab } \\
\text { Municipalities }\end{array}$ \\
\hline A summon board served at the time of & $\mathbf{0 . 0 4 0 ^ { * * }}$ & 0.001 & $\mathbf{0 . 0 4 2 *}$ \\
Knesset election & $(0.017)$ & $(0.003)$ & $(0.021)$ \\
& 0.021 & -0.001 & 0.017 \\
With an appointed accountant at the time of & $(0.013)$ & $(0.002)$ & $(0.020)$ \\
Knesset election & 0.16 & 0.05 & 0.35 \\
& 571 & 360 & 211 \\
\hline Adjusted R-Squared & 45 & 14 & 31 \\
Observations & 185 & 47 & 138 \\
Observations with a summon board & 34 & 8 & 26 \\
Observations with an appointed accountant & 195 & 120 & 75 \\
Observations with a summon board and an & & & \\
appointed accountant & & & \\
Number of municipalities & &
\end{tabular}

Notes: see table $5 a$. 
Table 10a: The effect of a summon board on voter turnout in national elections Sensitivity analysis: both the mayor and council members had been removed

\begin{tabular}{lccc}
\hline \hline \multicolumn{1}{c}{ Variable } & $\begin{array}{c}\text { All } \\
\text { Municipalities }\end{array}$ & $\begin{array}{c}\text { Jewish } \\
\text { Municipalities }\end{array}$ & $\begin{array}{c}\text { Arab } \\
\text { Municipalities }\end{array}$ \\
\hline $\begin{array}{l}\text { A summon board served at the time of Knesset } \\
\text { election }\end{array}$ & 0.012 & $\mathbf{- 0 . 0 1 1}^{* * *}$ & $\mathbf{0 . 0 5 2 * *}$ \\
& $(0.012)$ & $(0.004)$ & $(0.021)$ \\
\hline Adjusted R-Squared & 0.14 & 0.65 & 0.19 \\
Observations & 571 & 360 & 211 \\
Observations with a summon board & 36 & 13 & 23 \\
Number of municipalities & 195 & 120 & 75 \\
\hline
\end{tabular}

Notes: see table $5 a$.

Table 10b: The effect of a summon board on voting share for Arabs parties Sensitivity analysis: both the mayor and council members had been removed

\begin{tabular}{lccc}
\hline \hline \multicolumn{1}{c}{ Variable } & $\begin{array}{c}\text { All } \\
\text { Municipalities }\end{array}$ & $\begin{array}{c}\text { Jewish } \\
\text { Municipalities }\end{array}$ & $\begin{array}{c}\text { Arab } \\
\text { Municipalities }\end{array}$ \\
\hline $\begin{array}{l}\text { A summon board served at the time of Knesset } \\
\text { election }\end{array}$ & $\mathbf{0 . 0 4 6 * *}$ & 0.002 & 0.048 \\
& $(0.022)$ & $(0.003)$ & $(0.030)$ \\
\hline Adjusted R-Squared & 0.15 & 0.05 & 0.34 \\
Observations & 571 & 360 & 211 \\
Observations with a summon board & 36 & 13 & 23 \\
Number of municipalities & 195 & 120 & 75 \\
\hline
\end{tabular}

Notes: see table $5 a$. 
Table 11a: Reverse causality - the effect of voter turnout on a summon board in 2007

\begin{tabular}{lccc}
\hline \hline \multirow{2}{*}{ Variable } & \multicolumn{2}{c}{ Summon board served at 2007 } \\
\cline { 2 - 4 } & All Municipalities & $\begin{array}{c}\text { Jewish } \\
\text { Municipalities }\end{array}$ & $\begin{array}{c}\text { Arab } \\
\text { Municipalities }\end{array}$ \\
\hline $\begin{array}{l}\text { Rate of change in voter turnout in } \\
\text { Knesset election (2003-2006) }\end{array}$ & 0.074 & -0.452 & -0.081 \\
& $(0.310)$ & $(0.521)$ & $(0.459)$ \\
constant & $\mathbf{0 . 1 3 3 ^ { * * * }}$ & 0.015 & $\mathbf{0 . 2 1 4 * * *}$ \\
& $(0.041)$ & $(0.067)$ & $(0.063)$ \\
\hline $\begin{array}{l}\text { Adjusted R-Squared } \\
\text { Observations }\end{array}$ & -0.01 & 0 & -0.02 \\
\hline
\end{tabular}

Notes: see table $5 a$.

Table 11b: Reverse causality - the effect of voting share for Arab parties on a summon board in 2007

\begin{tabular}{lccc}
\hline \hline \multirow{2}{*}{ Variable } & \multicolumn{2}{c}{ Summon board served at 2007 } \\
\cline { 2 - 4 } & All Municipalities & $\begin{array}{c}\text { Jewish } \\
\text { Municipalities }\end{array}$ & $\begin{array}{c}\text { Arab } \\
\text { Municipalities }\end{array}$ \\
\hline $\begin{array}{l}\text { Rate of change in voting turnout for } \\
\text { Arabs parties (2003-2006) }\end{array}$ & -0.010 & -0.007 & -0.036 \\
& $(0.037)$ & $(0.039)$ & $(0.066)$ \\
constant & $\mathbf{0 . 1 2 7 ^ { * * * }}$ & $\mathbf{0 . 0 6 6 ^ { * * * }}$ & $\mathbf{0 . 2 2 7 ^ { * * * }}$ \\
& $(0.026)$ & $(0.024)$ & $(0.052)$ \\
\hline $\begin{array}{l}\text { Adjusted R-Squared } \\
\text { Observations }\end{array}$ & -0.01 & -0.01 & -0.01 \\
\hline
\end{tabular}

Notes: see table 5a. 